\title{
USING OF T-SPOT.TB AND MANTOUX TESTS IN DIAGNOSIS OF $M$. tuberculosis INFECTION IN BCG VACCINATED CHILDREN AGED FIVE AND YOUNGER
}

\author{
Iveta Ozere, G̦irts Skenders, Iveta Līduma, Olga Bobrikova, Zita Lauska, Anita Skangale, \\ Anita Jagmane, Vita Kalnin,a, and Vaira Leimane
}

State Agency of Tuberculosis and Lung Diseases of Latvia, p.o. Cekule, Rīgas raj., LV- 2118, LATVIA;

e-mail: Iveta.Ozere@ tuberculosis.Iv

Communicated by Ludmila Vīksna

\begin{abstract}
Infection with $\mathrm{M}$. tuberculosis (MT) is difficult to diagnose in young BCG (Bacillus Calmette-Guérin) vaccinated children using Mantoux test alone, as a positive test result may be due to infection with MT and previous BCG vaccination. We aimed to test the T-SPOT.TB test for $B C G$-vaccinated children aged five and younger in two groups - with or without contact with an active tuberculosis (ATB) patient. Prospectively a study group of 121 children (having contact with ATB patient) and a control group of 64 children (without known contact with ATB patient) were examined using Mantoux and T-SPOT.TB tests. The T-SPOT.TB test was positive in 66 (54.5\%) study group children and in $2(3.1 \%)$ control group children $(P<0.01)$. Induration in the Mantoux test $\geq 10 \mathrm{~mm}$ was observed in 62 (91.0\%) of 68 T-SPOT.TB positive children, and $34(29.1 \%)$ of 117 T-SPOT.TB negative children $(P<0.01)$. In the group with a negative T-SPOT.TB result boosting of the Mantoux test was observed in $21(66 \%)$ of 32 children who had received repeated Mantoux testing before being included in the study. According to the results, the application of the T-SPOT.TB test is reasonable for primary contact children evaluation and follow-up contact children for whom primary tests did not confirm infection with MT.
\end{abstract}

Key words: Mantoux test, T-SPOT.TB test, tuberculosis, children.

\section{INTRODUCTION}

The most susceptible group of patients to tuberculosis are children aged five and younger. Risk of the disease following primary infection without preventive treatment is up to $50 \%$ in children younger than 12 months. This proportion gradually declines with age and reaches about $5 \%$ at five years (Marais et al., 2004).

Unfortunately, the diagnosis of $M$. tuberculosis infection using the intracutaneous tuberculin skin test (also known as the Mantoux test) alone is difficult particularly in this more sensitive age group mainly because of previous BCG (Bacillus Calmette-Guérin) vaccination. The Mantoux test measures the delayed type hypersensitivity response to intracutaneously introduced purified protein derivative (PPD), which represents a crude mixture of mycobacterial antigens, many of which are shared among $M$. tuberculosis, $M$. bovis $\mathrm{BCG}$, and various non-tuberculous mycobacteria. BCG vaccination elicits a local cutaneous delayed type hypersensitivity response to PPD antigens in sensitised individuals and is the major agent contributing to a false positive Mantoux test result. When BCG is given during infancy, its capacity to induce a false positive Mantoux test declines with age.
Most children vaccinated as infants show a non-reactive tuberculin skin test at five years of age, but still can be false positive up to 15 years of age and even in adulthood (Karalliedde et al., 1987; Menzies and Vissandjee, 1992; Khan and Starke, 1995; Bozaykut et al., 2002; Wang et al., 2002). The BCG effect on boosting of a repeated Mantoux test is particularly relevant in follow-up children who have had contact with an ATB patient (Wang et al., 2002).

Until recently, the Mantoux test was the only method for detection of $M$. tuberculosis infection. However, the drawbacks of test are well known (low specificity in BCG vaccinated population, low sensitivity particularly in immunosuppressed patients, errors in measuring, booster phenomenon) (Pai, 2005; Richeldi, 2006), but the decision for preventive treatment was based on this only available test. As the result, many children received unnecessary isoniazid preventive treatment, while others were not treated and had developed active tuberculosis. Up to now BCG vaccination is widely used throughout the world. In Latvia, with a total tuberculosis incidence rate 47.2 per 100,000 population in $2007, B C G$ is given in all healthy newborns, and coverage of BCG is more than $99 \%$ of infants until one year of age. Therefore, correct interpretation of the Mantoux test is not 
available in all children, and particularly in those aged five and younger who have had contact with active tuberculosis patients.

Recent advances in $M$. tuberculosis genomics have identified a genomic segment, RD1 (region of difference 1), that is present in the $M$. tuberculosis complex, but absent from all strains of $M$. bovis BCG and almost all environmental mycobacteria (Mahairas et al., 1996). Early secretory antigenic target-6 (ESAT-6) and culture filtrate protein 10 (CFP-10) are secreted proteins encoded by RD1, and thus, specific for $M$. tuberculosis. These proteins are major targets for interferon-gamma (IFN- $\gamma$ ) secreting T-cells in $M$. tuberculosis-infected individuals. Activated blood effector T-cells (CD4 and CD8) produce a cytokine IFN- $\gamma$ in response to previously encountered $M$. tuberculosis specific antigens.

Blood T-cell based IFN- $\gamma$ release assays (TIGRAs) have been developed as an alternative approach to the tuberculin skin test for detection of $M$. tuberculosis infection. TIGRAs are based on the ex vivo detection of IFN- $\gamma$ released from presensitised $M$. tuberculosis-specific T-cells in response to two immunodominant $M$. tuberculosis secreted proteins: ESAT-6 and CFP-10 (Lalvani et al., 2002; Lalvani, 2003; Richeldi, 2006).

Currently three commercial blood T-cell based assays are available: QuantiFERON-TB Gold, QuantiFERON-TB in-tube, which use the enzyme-linked immunosorbent assay (ELISA) platform, and Lalvani ELISpot, which now is commercially available as the T-SPOT.TB (Oxford Immunotec Limited). The T-SPOT.TB test is based on enzyme-linked immunospot assay technology for the detection of T-cells producing IFN- $\gamma$ in response to stimulation by $M$. tuberculosis specific antigens ESAT-6 and CFP-10. Current evidence suggests very high, even up to $100 \%$ diagnostic specificity of new blood TIGRAs for diagnosis of M. tuberculosis infection, because they are not confounded by prior BCG vaccination (Brock et al., 2004; Ferrara et al., 2006; Lee et al., 2006; Richeldi, 2006). The sensitivity of blood tests is also higher than the Mantoux test, and for the ELISpot test sensitivity has been reported ranging from 83 to $97 \%$ (Pathan et al., 2001; Liebeschuetz et al., 2004; Meier et al., 2005; Ferrara et al., 2006; Richeldi, 2006).

The aim of the study was to compare the performance of the Mantoux test and T-SPOT.TB test for diagnosis of M. tuberculosis infection (active and latent) in immunocompetent BCG vaccinated children aged five and younger, and to develop recommendations for use of the T-SPOT.TB test in Latvia in this age group.

\section{MATERIALS AND METHODS}

Study population. This prospective cross-sectional study was performed during February 2006 and December 2007 at the Paediatric Department of State Agency of Tuberculosis and Lung Diseases (SATLD). SATLD serves the coun- try for evaluation for tuberculosis. The study population was composed of BCG-vaccinated children aged five and younger, without conditions causing immunosuppression.

The study group comprised:

- all consecutive predefined children admitted into the SATLD because of suspected M. tuberculosis infection (active and latent);

- all consecutive outpatient predefined children from Rīga and Rīga district undergoing evaluation because of suspected $M$. tuberculosis infection (active and latent).

The ethics committee of the SATLD approved the study. Written consent for each patient was given by caregivers.

Sampling was stratified in two groups:

- the study group included 121 BCG-vaccinated children aged five and younger having close contact with an active tuberculosis patient (ATBP);

- the control group was composed of 64 BCG-vaccinated children aged five and younger without known contact with ATBP. They were checked for tuberculosis because of a positive Mantoux test and/or clinical suspects on tuberculosis.

Each child was examined clinically, radiologically, using the Mantoux test and T-SPOT.TB test. Inpatient children were also examined bacteriologically.

Procedures. The Mantoux test was performed by intracutaneous injection of 2 T.U. Tuberculin PPD RT 23 SSI. The resulting induration was measured after 72 hours and recorded in millimetre. Injection and reading of the test was carried out by trained staff inpatient and outpatient. In 174 patients the median time lag between the performance of two tests was $15.9(0-90)$ days. All except seven were tested with Mantoux test before T-SPOT.TB test. Eleven patients of study group were tested with the Mantoux test 3 6 months before the T-SPOT.TB test. To avoid a boosting effect, the Mantoux test was not repeated before the TSPOT.TB test.

Accordingly to guidelines for determining a positive tuberculin skin test reaction in recent contacts of tuberculosis case, induration $5 \geq \mathrm{mm}$ was defined as a positive test result (Anonymous, 2000).

The T-SPOT.TB test was performed in compliance with the protocol provided by the manufacturer Oxford Immunotec (Anonymous, 2006a). A sample of $4 \mathrm{ml}$ venous blood was drawn from each patient. Within $1-4$ hours after sample collection, the peripheral blood mononuclear cells (PBMCs) were separated by centrifugation and seeded $\left(2.5 \times 10^{5}\right.$ PBMCs per well) on a plate precoated with antibody against IFN- $\gamma$. Four wells were used for each sample: a nil control well contained the cell suspension in medium alone to test for non-specific cytokine secretion; positive control well was stimulated with phytohaemagglutinin to test for 
T-SPOT.TB AND MANTOUX TEST RESULTS IN STUDY AND CONTROL GROUP PATIENTS

\begin{tabular}{l|c|c|c|c}
\multicolumn{1}{c|}{ Tests } & \multicolumn{3}{|c|}{ Study group $(\mathrm{n}=121)$} & \multicolumn{2}{c}{ Control group $(\mathrm{n}=64)$} \\
\hline Mantoux tests (size of induration in mm) & $<5$ negative & $\geq 5<10$ & $\geq 10$ & $<5$ negative \\
Number of patients having a positive T-SPOT.TB test $(\mathrm{n}=68)$ & 3 & 3 & 60 & - \\
Number of patients having a negative T-SPOT.TB test $(\mathrm{n}=117)$ & 23 & 12 & 20 & 38
\end{tabular}

PBMCs viability; panel A well contained peptides encompassing the antigen ESAT-6, panel B well contained peptides encompassing the antigen CFP-10. The wells were incubated in a humidified incubator at $37{ }^{\circ} \mathrm{C}$ and $5 \%$ carbon dioxide for 16 - 20 hours. After incubation wells were washed and incubated with second conjugated antibody directed to a different epitope on the IFN- $\gamma$ molecule compared to the antibody precoating the plate. Spot forming cells (SFC) were counted in each well using a magnifying glass. The result was scored as positive if panel $\mathrm{A}$ and/ or panel B wells contained at least 5 SFC or more $\geq 2$ times SFC compared with the negative control well. Test results were available after 24 hours.

T-SPOT.TB tests were carried out within a week of presentation at the hospital before any antituberculosis therapy was commenced.

Definitions. Close contact with an active lung tuberculosis patient according to the WHO was defined as child living in the same household as a source case or in frequent contact with a source case (Anonymous, 2006b).

Active lung tuberculosis patient was defined as a bacteriologically confirmed (smear and/or culture positive) lung tuberculosis patient, or a person whose diagnosis of active lung tuberculosis was based on clinical case definition or diagnosed on autopsy.

The statistical analysis was performed using the $\chi^{2}$ test. A Yates corrected $P$ value 0.05 was considered as significant. Odds ratios with $95 \%$ confidence interval were calculated (EpiInfo version 6, Statcalc).

\section{RESULTS}

In total, 185 BCG-vaccinated children aged five and younger were included in the investigation. BCG vaccination was documented in all 185 patients, scar or papula (in infants) was visible in 104 (86\%) of study group and in 54 $(84 \%)$ of control group patients.

The T-SPOT.TB test was positive in $66(54.5 \%)$ of the study group and only in $2(3.1 \%)$ of control group patients $\left(P<0.01 ; \chi^{2}=45.43\right.$; OR 37.2 with $95 \%$ CI $\left.8.4-159.0\right)$ (Table 1). One of the control group patients having a positive T-SPOT.TB test was a three-year-old boy diagnosed with tuberculosis pleurisy. While the tuberculosis was not confirmed bacteriologically and histologically, there was a little doubt about diagnosis, because the child had inthrathoracic adenopathy associated with pleural collection, not resolving on non-specific antibacterial treatment and Mantoux test conversion during the last year. The other five-year-old control group patient having a positive T-SPOT.TB test was diagnosed with latent tuberculosis infection (LTBI). He had a Mantoux test conversion from 0 to $22 \mathrm{~mm}$ of induration within last year.

Significantly more positive T-SPOT.TB tests occurred in children, whose infectious source cases were sputum smear and culture positive for $M$. tuberculosis compared with those whose infectious source cases were only sputum culture positive $\left(P<0.05 ; \chi^{2}=5.44 ; \mathrm{OR}=3.46\right.$ with $95 \% \mathrm{CI}$ 1.2 - 10.4) (Table 2).

Most T-SPOT.TB-positive children also had a positive Mantoux test - induration $\geq 5 \mathrm{~mm}$ in $65(95.6 \%)$ children and induration $\geq 10 \mathrm{~mm}$ in $62(91.1 \%)$ children (Table 1$)$. Only three patients had a positive T-SPOT.TB and negative Mantoux test (Table 3). The Mantoux test (3 mm of induration) was performed for one of them within a week of diagnosing ATB in an infectious source case. The T-SPOT.TB test was performed three months later. The explanation for the negative Mantoux test might have been the short time for test conversion. Another patient had the Mantoux and T-SPOT.TB tests performed 17 months after diagnosis of ATB in an infectious source case. The Mantoux test induration was $3 \mathrm{~mm}$, despite a positive T-SPOT.TB test. The third child was given a T-SPOT.TB test 2.5 months after the Mantoux test. His infectious source case was clinically healthy, diagnosed with TB by prophylactic X-ray screening.

Table 2

CHARACTERISTICS OF INFECTIOUS SOURCE CASES FOR CHILDREN OF THE STUDY GROUP

\begin{tabular}{|c|c|c|c|}
\hline $\begin{array}{l}\text { Infectiousness of } \\
\text { the source case }\end{array}$ & $\begin{array}{c}\text { Number of } \\
\text { children having a } \\
\text { positive } \\
\text { T-SPOT.TB test } \\
(\mathrm{n}=66)\end{array}$ & $\begin{array}{c}\text { Number of } \\
\text { children having a } \\
\text { negative } \\
\text { T-SPOT.TB test } \\
(\mathrm{n}=55)\end{array}$ & Statistics \\
\hline $\begin{array}{l}\text { Sputum smear } \\
+/ \text { culture }+\end{array}$ & 56 & 37 & $\begin{array}{c}P<0.05 ; \chi^{2}= \\
5.44 ; \mathrm{OR}=3.46 \\
\text { with } 95 \% \mathrm{CI} \\
1.2-10.4\end{array}$ \\
\hline $\begin{array}{l}\text { Sputum smear } \\
\text {-/culture }+\end{array}$ & 7 & 16 & \\
\hline $\begin{array}{l}\text { Sputum smear } \\
+/ \text { culture - }\end{array}$ & 0 & 1 & \\
\hline $\begin{array}{l}\text { Sputum smear } \\
\text {-/culture - }\end{array}$ & 1 & 1 & \\
\hline $\begin{array}{l}\text { Diagnosed on au- } \\
\text { topsy }\end{array}$ & 2 & 0 & \\
\hline
\end{tabular}


PATIENTS OF THE STUDY GROUP HAVING A POSITIVE T-SPOT.TB AND NEGATIVE MANTOUX TEST RESULT

\begin{tabular}{|c|c|c|c|c|c|c|}
\hline \multirow[t]{2}{*}{ No } & \multirow[t]{2}{*}{ Age } & \multirow{2}{*}{$\begin{array}{c}\text { Infectiousness of source } \\
\text { case }\end{array}$} & \multirow[t]{2}{*}{ BCG scar } & \multicolumn{2}{|c|}{ T-SPOT.TB test } & \multirow[t]{2}{*}{ Diagnosis in child } \\
\hline & & & & $\begin{array}{c}\text { Panel A } \\
\text { number of spots }\end{array}$ & $\begin{array}{c}\text { Panel B } \\
\text { number of spots }\end{array}$ & \\
\hline 2 & 3 years & $\begin{array}{c}\text { Sputum } \\
\text { smear }+/ \text { culture }+\end{array}$ & 6 & 0 & 7 & Latent tuberculosis infection \\
\hline 3 & 2 years & $\begin{array}{c}\text { Sputum } \\
\text { smear - / culture - }\end{array}$ & 5 & 150 & 100 & Latent tuberculosis infection \\
\hline
\end{tabular}

In the study group patients the time lag in between diagnosis of ATB in a source case and performing the T-SPOT.TB test varied from 1 week to 17 months.

Distribution of diagnoses in patients of the study group is shown in Figure 1. Asymptomatic children having normal radiology and a negative T-SPOT.TB test result were assumed as not infected with M. tuberculosis despite a positive Mantoux test, and were diagnosed with exposure. Asymptomatic children with normal radiology having a positive T-SPOT.TB test result were assumed as infected with $M$. tuberculosis and were diagnosed with LTBI. Nine patients of 47 (19\%) having radiological findings consistent with ATB were diagnosed with active tuberculosis, despite a negative T-SPOT.TB test result. Detailed analysis of those nine patients diagnosed with ATB is demonstrated in Table 4. In 8 of 9 patients diagnosed with active tuberculosis, despite a negative initial T-SPOT.TB test, follow-up with TSPOT.TB was available on a non-regular basis, which showed positive conversion in three children after some period of treatment.
Altogether $75(62 \%)$ of 121 study group children and 2 (3.1\%) of 64 control group children were diagnosed with $M$. tuberculosis infection (ATB and LTBI).

The proportion of children with a positive Mantoux test was significantly higher in the T-SPOT.TB test positive group $\left(P<0.01 ; \chi^{2}=41.21 ;\right.$ OR $23.60,95 \%$ CI $\left.7.0-79.4\right)$, the Mantoux test was positive in $32(58.2 \%)$ of the study group and $24(38.7 \%)$ of control group patients who also had a negative T-SPOT.TB test result (Table 1). For children having a negative T-SPOT.TB test with a positive Mantoux test, boosting of the Mantoux test was observed in 21 (66\%) of 32 children. These 32 children had received repeated Mantoux testing before being included in the study (in the control group 16 children were repeatedly tested, boosting occurred in eight cases; in the study group 16 children received repeated testing, boosting occurred in 13).

\section{DISCUSSION}

We have compared in routine clinical practise the performance of two immunological methods - Mantoux test and

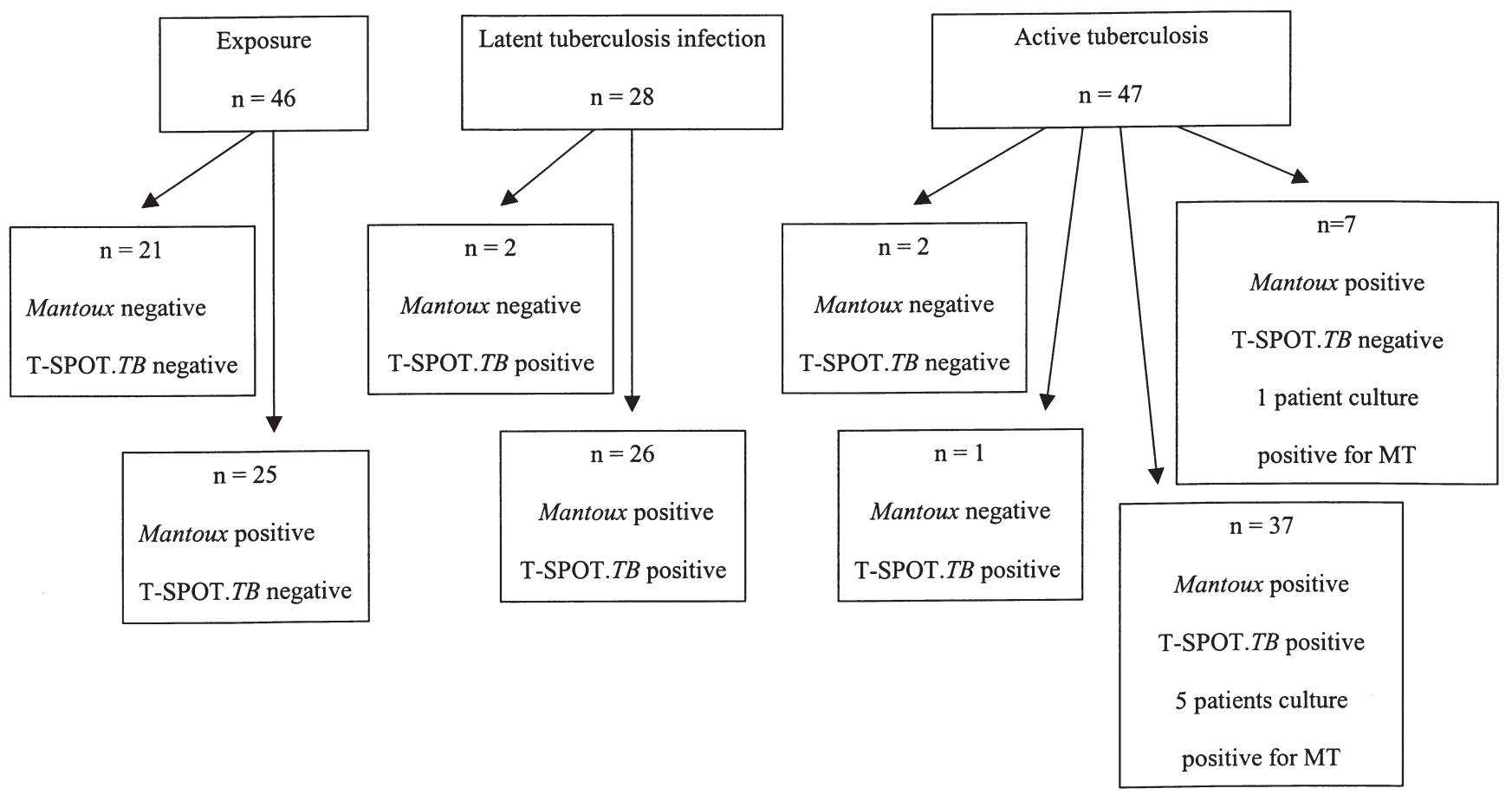

Fig. 1. Diagnoses in patients of the study group $(\mathrm{n}=121)$ 
CHARACTERISTICS OF PATIENTS OF THE STUDY GROUP HAVING A NEGATIVE T-SPOT.TB RESULT DIAGNOSED WITH ACTIVE TUBERCULOSIS

\begin{tabular}{|c|c|c|c|}
\hline Age & $\begin{array}{l}\text { Mantoux test (size of } \\
\text { induration in } \mathrm{mm} \text { ) }\end{array}$ & $\begin{array}{c}\text { Characteristics of } \\
\text { sputa of infectious source cases }\end{array}$ & Chest X-ray and CT findings \\
\hline 6 months & 5 & Smear $+/$ culture + & $\begin{array}{l}\text { Right sided hilar adenopathy and infiltrative shadow } \\
\text { in right } 6^{\text {th }} \mathrm{sg}\end{array}$ \\
\hline 6 months & 25 & $\begin{array}{l}\text { Smear }+/ \text { culture }+ \\
\quad \text { MDR TB case }\end{array}$ & $\begin{array}{l}\text { Deformated left hilus, nodular shadows in right } 3^{\text {rd }} \\
\text { and } 10^{\text {th }} \mathrm{sg}\end{array}$ \\
\hline * 9 months & 20 & Smear + / culture + & $\begin{array}{l}\text { Calcified right bronchopulmonary and subcarinal } \\
\text { lymph nodes }\end{array}$ \\
\hline ** 13 months & 10 & Smear $+/$ culture + & $\begin{array}{c}\text { Infiltrative shadow in right } 3^{\text {rd }} \text { and } 4^{\text {th }} \mathrm{sg} \text {, nodular } \\
\text { shadows in right } 10^{\text {th }} \text { and lingular } \mathrm{sg}\end{array}$ \\
\hline 20 months & 15 & $\begin{array}{l}\text { Smear }+/ \text { culture }+ \\
\quad \text { MDR TB case }\end{array}$ & $\begin{array}{l}\text { Calcified subcarinal and both sided } \\
\text { bronchopulmonary lymph nodes }\end{array}$ \\
\hline$* * * 24$ months & 15 & Smear + / culture + & $\begin{array}{l}\text { Nodular shadow in left } 10^{\text {th }} \mathrm{sg} \text {, calcified } \\
\text { bronchopulmonary lymph nodes }\end{array}$ \\
\hline 28 months & 8 & Smear $+/$ culture + & $\begin{array}{c}\text { Nodular shadows in right } 6^{\text {th }} \mathrm{sg} \text { and ribbon-shaped } \\
\text { shadows in the middle lobe }\end{array}$ \\
\hline 9 months & 0 & Smear - / culture + & Infiltrative shadow in right $6^{\text {th }} \mathrm{sg}$ \\
\hline 30 months & 0 & Smear - / culture + & Infiltrative shadows in right $2^{\text {nd }}$ and $6^{\text {th }} \mathrm{sg}$ \\
\hline
\end{tabular}

T-SPOT. TB test for diagnosis of M. tuberculosis infection in immunocompetent BCG-vaccinated children aged five and younger, who represent our general population in this age group. Over $99 \%$ of children have received BCG vaccination by the age of one year, and immunosuppressive diseases including HIV infection are rare in children in Latvia. Combining the results of Mantoux test, T-SPOT.TB test and radiological examination, active tuberculosis and latent tuberculosis infection was diagnosed in 75 (62\%) children having close contact with an adult tuberculosis patient, while only $2(3.1 \%)$ children were detected with $M$. tuberculosis infection in the control group without contact history (Table 1). More T-SPOT.TB positive tests occured in the children whose infectious source cases were sputum smear and culture positive for M. tuberculosis, comparing with those whose source cases were only sputum culture positive (Table 2). These results are consistent with many previous studies, which found a significant correlation between frequency of T-SPOT.TB test positive result and history of exposure (Ewer et al., 2003; Richeldi et al., 2004; Zellweger et al., 2005).

Negative T-SPOT.TB test results for BCG-vaccinated unexposed subjects demonstrate its high specificity up to $100 \%$, i.e. the results are expected to be negative (Lalvani et al., 2001; Pathan et al., 2001; Chapman et al., 2002; Liebeschuetz et al., 2004). In our study the specificity of TSPOT.TB test was $96.9 \%$ in BCG vaccinated unexposed controls (T-SPOT.TB was positive in 2 out of 64 controls, Table 1). This lower specificity can be explained by the epidemiological situation in Latvia - the total tuberculosis incidence rate was 49.7 per 100,000 population in 2006 , and exposure due to social contacts by unidentified ATB patients can occur. Application of the T-SPOT.TB test also demonstrated $39 \%$ (24 of 62, Table 1) false positive Mantoux test results in unexposed BCG-vaccinated controls. Our study showed that there is no need to use the TSPOT.TB test on a regular basis in Mantoux test positive BCG-vaccinated unexposed children.

In our study the diagnosis of latent tuberculosis infection was based on a positive T-SPOT.TB test in asymptomatic patients after exclusion of active tuberculosis radiologically. However, the "gold standard" for diagnosis of M. tuberculosis infection has not yet been defined. It seems reasonable to consider the exposed child having a positive T-SPOT.TB test as infected, as this test detects recently activated lymphocytes with immediate effector function driven by $M$. tuberculosis specific antigens, and these children are candidates for preventive treatment. Moreover, only three $(4.5 \%)$ of 66 exposed children with a positive T-SPOT.TB test had a negative Mantoux test, which indirectly may confirm the unlikely false positive T-SPOT.TB test results.

It is difficult to interpret the 55 study group children with a negative T-SPOT.TB test result (Table 1). Reliable exclusion of infection in all exposed children having a negative T-SPOT.TB is not possible in this group due to several reasons. One problem is "window period", when T cells become specifically activated after infection. The estimated interval between infection and detectable test reactivity of the Mantoux test is 2 to 10 weeks (Morantz, 2006). The "window period" is not precisely established for the TSPOT.TB test, but is commonly accepted to be the same as 
for Mantoux method. Unfortunately, neither the start of the infectiousness of the source case, nor time-point of establishment of infection in recipient can be accurately detected. On the basis on expert opinion, the beginning of the infectious period is estimated as three months before positive findings consistent with tuberculosis in clinically symptomatic sputum smear positive and negative patients, and one month in clinically healthy without cavitary disease sputum smear negative patients (Anonymous, 2005).

The time lag between diagnosis of ATB in a source case and performing of the T-SPOT.TB in our children varied from one week to 17 months. One of the limitations of our study was that the data were analysed without taking into consideration the time lag between diagnosis of tuberculosis in an infectious source case and performance of the TSPOT.TB test in child. It can be assumed that some patients were tested with T-SPOT.TB too early, during the "window period", which can explain the "false" negative result. Some patients, particularly those having a negative Mantoux result, were likely not infected with tuberculosis. Nine of 55 exposed children were diagnosed with active tuberculosis despite a negative T-SPOT.TB test (Table 4). All of them had close contact to infectious source cases, seven tested positive with Mantoux test, one was culture positive for $M$. tuberculosis, and taking into consideration radiological findings, active tuberculosis could not be excluded at the time of diagnosis. All nine children improved radiologically on antituberculosis treatment. Eight of them were followed up with a T-SPOT.TB test on a non-regular basis, and the T-SPOT.TB test switched to positive after some period of treatment in three children (one of them bacteriologically confirmed). M. tuberculosis infection is a prerequisite for developing active tuberculosis, and immunological tests should assist for diagnosis confirming infection with $M$. tuberculosis. The sensitivity of ELIspot was $83 \%$ in South African children with high prevalence of HIV coinfection and malnutrition (Liebeshuetz et al., 2004). In our study $81 \%$ of active tuberculosis patients without impaired immunity were T-SPOT.TB test positive before treatment, and $87 \%$ were positive after some period of treatment. Studies have shown that $M$. tuberculosis-infected subjects with lower antigen loads have higher levels of ESAT- 6-specific $\mathrm{T}$ cells, and frequencies of ESAT-6-specific CD4 T cells decay progressively with treatment (Pathan et al., 2001; Ewer et al., 2006). None of our T-SPOT.TB test negative ATB patients had advanced disease, and perhaps the antigen load was not high before treatment.

It is unclear, why the sensitivity of the first blood test was low in our study, but it is clear that a negative T-SPOT.TB test result in exposed children has to be interpreted in context with other examination results and does not reliably exclude infection with $M$. tuberculosis and particularly active tuberculosis. Hill et al (2006) compared ELISPOT to the Mantoux test in healthy household contact children between six months and 14 years of age in a tuberculosis-endemic tropical setting (in Gambia). The authors concluded that the ELISPOT assay using M. tuberculosis-specific antigens was not as sensitive for the diagnosis of $M$. tuberculosis infection from recent exposure as the tuberculin skin test and offered no added benefit with respect to the confounding effect of BCG vaccination. The time interval between diagnosis of tuberculosis in infectious source cases and performance of the first T-SPOT.TB tests in the three patients who became positive after treatment, varied from one week to six months. In all three cases the infectious sources were symptomatic for a long time before diagnosis of ATB. Based on our raised ideas, those three children should have converted their blood tests until initial testing and diagnosis.

Giving the results of our study, the reliability of the T-SPOT.TB test for exclusion of $M$. tuberculosis infection in exposed young children is unclear. On the one hand, IFN- $\gamma$ production detected by ELISpot, except in the first weeks of life, is not age-dependent, probably, because of ELISpot's high analytical sensitivity, which enables it to detect even low numbers of IFN- $\gamma$ - secreting $\mathrm{T}$ cells (Lalvani and Millington, 2007). On the other hand, little is known about performance of TIGRAs tests in children aged five and younger. More studies are necessary to identify the optimal interval between the last time of exposure and test performance for reliable results to confirm or to exclude infection with M. tuberculosis.

Based on the study results we concluded that T-SPOT.TB test offers an excellent opportunity for confirmation of $M$. tuberculosis infection in exposed BCG vaccinated children, and for exclusion of $M$. tuberculosis infection in unexposed BCG vaccinated children as well. Simultaneous applying of T-SPOT.TB and Mantoux tests also showed boosting and false positive Mantoux test results in BCG vaccinated children. In immunocompetent BCG vaccinated children aged five years of younger, the T-SPOT.TB test has to be used in primary contact children evaluation, particularly those having induration of Mantoux test $\geq 10 \mathrm{~mm}$, and for follow-up contact children whose primary tests did not confirm infection with $M$. tuberculosis.

\section{ACKNOWLEDGEMENTS}

The study was funded in part by grant No. 07.2040 from the Latvian Council of Science and in part by the Centers for Disease Control and Prevention, Atlanta, USA.

\section{REFERENCES}

Anonymous (2000). Centers for Disease Control and Prevention. Targeted tuberculin testing and treatment of latent tuberculosis infection. MMWR (Morbidity and Mortality Weekly Report), 49 (RR-6), 24.

Anonymous (2005). Centers for Disease Control and Prevention. Guidelines for the Investigation of Contact Persons with Infectious Tuberculosis. $M M W R$, Recommendations and Reports, 54 (RR15), 1-37.

Anonymous (2006a). Oxford Immunotec Limited. T-SPOT.TB. Package insert: 3 .

Anonymous (2006b). World Health Organisation. Guidance for national tuberculosis programmes on the management of tuberculosis in children. WHO/HTM/TB/2006.371. WHO/FCH/CAH/2006.7, 16-19. 
Bozaykut, A., Ozahi Ipek, I., Ozkars, M. Y., Pulat Seren L., Atay, E., Atay, Z. (2002). Effect of BCG vaccine on tuberculin skin tests in 1-6-year-old children. Acta Paediatrica, 91(2), 235-238.

Brock, I., Weldingh, K., Lillebaek, T., Follmann, F., Anderson, P. (2004). Comparison to Tuberculin Skin Test and New Specific Blood Test in Tuberculosis Contacts. Amer. J. Respir. Crit. Care Med., 170, 65-69.

Chapman, A.L., Muncanta, M., Wilkinson, K.A., Pathan, A.A., Ewer, K., Ayles, H., Reece, W.H., Mwinga, A., Godfrey-Faussett, P., Lalvani, A. (2002). Rapid detection of active and latent tuberculosis infection in HIV-positive individuals by enumeration of Mycobacterium tuberculosis-specific T cells. AIDS, 16, 2285-2293.

Ewer, K., Deeks, J., Alvarez, L., Bryant, G., Waller, S., Andersen, P., Monk, P., Lalvani, A. (2003). Comparison of T-cell-based assay with tuberculin skin test for diagnosis of Mycobacterium tuberculosis infection in a school tuberculosis outbreak. Lancet, 361(9364), 1168-1173.

Ewer, K., Millington, K.A., Deeks, J., Alvarez, L., Bryant, G., Lalvani, A. (2006). Dynamic antigen-specific T-cell responses after point-source exposure to Mycobacterium tuberculosis. Amer. J. Respir. Crit. Care Med., 174, 831-839.

Ferrara, G., Losi, M., D’Amico, R., Roversi, P., Piro, R., Meacci, M., Meccugni, B., Dori, I. M., Andreani, A., Bergamini, M.B., Mussini, C., Rumpianesi, F., Fabbri, L M., Richeldi, L. (2006). Use in routine clinical practice of two commercial blood tests for diagnosis of infection with $M y$ cobacterium tuberculosis: A prospective study. The Lancet, 367(9519), 1328-1334.

Hill, P.C., Brookes, R.H., Adetifa, I.M.O., Fox, A., Jackson-Sillah, D., Lugos, M.D., Marshall, R.J., Howie S.R.C., Corrah, T., Jeffries, D.J., Adegbola, R.A., McAdam, K.P.W.J. (2006). Comparison of enzyme-linked immunospot assay and tuberculin skin test in healthy children exposed to Mycobacterium tuberculosis. Pediatrics, 117(5), 1542-1548.

Karalliedde, S., Katugaha., L.P., Urogada, C.G. (1987). Tuberculin response of Sri Lankan children after BCG vaccination at birth. Tubercle, 68, 33-38.

Lalvani, A. (2003). Spotting latent infection: The path to better tuberculosis control. Thorax, 58, 960-918

Lalvani, A., Millington, K.A. (2007). T cell-based diagnosis of childhood tuberculosis infection. Curr. Opin. Infect. Dis., 20, 264-271.

Lalvani, A., Pathan, A.A., McShane, H., Wilkinson, R.J., Latif, M., Conlon, C.P., Pasvol, G., Hill, A.V. (2001). Rapid detection of Mycobacterium tuberculosis infection by enumeration of antigen specific T cells. Amer. J. Respir. Crit. Care Med., 163, 824-828.
Lee, J.Y., Choi, H.J., Park, I-N., Hong, S-B., Oh, Y-M., Lim, C-M., Lee, S.D., Koh, Y., Kim, W.S., Kim, W.D., Shim, T.S. (2006). Comparison of two commercial interferon- $\gamma$ assays for diagnosing Mycobacterium tuberculosis infection. Eur. Respir. J., 28, 24-30.

Liebeschuetz, S., Bamber, S., Ewer, K., Deeks, J., Pathan, A.A., Lalvani, A (2004). Diagnosis of tuberculosis in South African children with a T-cell based assay: A prospective cohort study. Lancet, 364, 2196-2203.

Marais, B.J., Gie, R.P., Schaaf, H S., Hesseling, A.C., Obihara, C.C., Starke, J.J., Enarson, D.A., Donald, P.R., Beyers, N. (2004). The natural history of childhood inthra-thoracic tuberculosis: A critical review of literature from pre-chemotherapy era. Int. J. Tuberc. Lung. Dis., 8(4), 392-402.

Meier, T., Eulenbruch, H.P., Wrighton-Smith, P., Enders, G., Regnath, T. (2005). Sensitivity of a new commercial enzyme-linked immunospot assay (T SPOT-TB) for diagnosis of tuberculosis in clinical practise. Eur. J. Clin. Microbiol. Inf. Dis., 24(8), 529-536.

Menzies, R., Vissandjee, B. (1992) Effect of bacilli Calmette-Guerin vaccination on tuberculin reactivity. Amer. Rev. Respir. Dis., 145, 621-625.

Morantz, C.A. (2006). Practise Guidelines. Guidelines Released for Investigation of Potential Contact with Infectious Tuberculosis. Amer. Family Physician, 73(8), 1-9.

Pai, M. (2005). Alternatives to the Tuberculin Skin Test: Interferon- $\gamma$ Assays in the Diagnosis of Mycobacterium tuberculosis Infection. Ind. J. Med. Microbiol., 23(3), 151-158.

Pathan, A.A., Wilkinson, K.A., Klenerman, P., McShane, H., Davidson, R.N., Pasvol, G., Hill, A.V., Lalvani, A. (2001). Direct ex vivo analysis of antigen-specific IFN-gamma-secreting CD4 cells in Mycobacterium tuberculosis infected individuals: Association with clinical disease state and effect of treatment. J. Immunol., 167, 5217-5225.

Richeldi, L. (2006) An update on the diagnosis of tuberculosis infection. Amer. J. Respir. Crit. Care Med., 174, 736-742.

Richeldi, L., Ewer, K., Losi, M., Bergamini, B. M., Roversi, P., Deeks, J., Fabbri, L.M., Lalvani, A. (2004). T cell-based tracking of multidrug resistant tuberculosis infection after brief exposure. Amer. J. Respir. Crit. Care Med., 170, 288-295.

Wang, L., Turner, M. O., Elwood, R. K., Schulzer, M., FitzGerald, J. M. (2002). A meta-analysis of the effect of bacilli Calmette Guerin vaccination on tuberculin skin test measurements. Thorax, 57, 804-809.

Zellweger, J-P., Zellweger, A., Ansermet, S., de Senarclens, B., Wringhton-Smith, P. (2005). Contact tracing using a new T-cell-based test: Better correlation with tuberculosis exposure than the tuberculin skin test. Int. J. Tuberc. Lung Dis., 9(11), 1242-1124.

Received 16 January 2009

\section{T-SPOT.TB UN MANTOUX TESTI M.tuberculosis INFEKCIJAS DIAGNOSTIKĀ BCG VAKCINĒTIEM BĒRNIEM LĪDZ PIECU GADU VECUMAM}

Izmantojot intrakutāno Mantoux testu, M. tuberculosis (MT) infekcijas diagnostika BCG (Bacillus Calmette-Guérin) vakcinētiem bērniem līdz piecu gadu vecumam ne vienmēr ir iespējama, jo pozitīvs Mantoux tests var būt gan inficēšanās ar MT, gan iepriekšējās BCG vakcinācijas rezultāts. Alternatīvā ex vivo T-SPOT.TB metode MT infekcijas diagnostikā pamatojas uz interferona- $\gamma$ izdalošo T šūnu skaita noteikšanu pēc to inkubācijas ar MT specifiskajiem antigēniem - ESAT-6 un CFP-10, līdz ar to BCG vakcinācija rezultātu neiespaido. Pētījuma mērkis bija novērtēt, kuru BCG vakcinētu bērnu līdz piecu gadu vecumam izmeklēšanā bez Mantoux metodes papildus ir nepieciešams pielietot T-SPOT.TB testu: bērniem, kuriem ir zināms kontakts ar aktīvas tuberkulozes (ATB) slimnieku, vai bērniem, kuriem nav zināms kontakts ar ATB slimnieku. Kopā prospektīvajā šḳērsgriezuma pētījumā tika iekḷauti 185 bērni, kuru izmeklēšanā tika izmantoti Mantoux un T-SPOT. TB testi: no tiem 121 pētāmajā grupā (ar zināmu kontaktu ar ATB slimnieku), bet 64 kontroles grupā (bez zināma kontakta ar ATB slimnieku). T-SPOT.TB tests bija pozitīvs $66(54,4 \%)$ pētāmās grupas un $2(3,1 \%)$ kontroles grupas bērniem $(P<0,01)$. Mantoux testa indurācija $\geq 10 \mathrm{~mm}$ bija $62(91 \%)$ no 68 T-SPOT.TB testa pozitīvajiem bērniem, un $34(29,1 \%)$ no 117 T-SPOT.TB testa negatîvajiem bērniem $(P<0,01)$. Mantoux testa indurācijas palielināšanās tika konstatēta tiem $21(66 \%)$ no 32 bērniem, kuriem šis tests bija izdarīts atkārtoti pirms iekḷaušanas pētījumā. Pētījuma rezultāti pamato T-SPOT.TB testa pielietošanas lietderību MT infekcijas diagnostikā, primāri izmeklējot bērnu pēc kontakta ar ATB slimnieku, kā arī to kontakta bērnu turpmākajā novērošanā, kuru primārās izmeklēšanas rezultāti bijuši neinformatīvi MT infekcijas diagnostikai. 